\title{
Identifying the effective factors and components in transferring learning to the work environment in in-service training of nurses in hospitals affiliated to the Social Security Organization
}

\author{
Sanaz Farhad ${ }_{2}$, Mohammad Hassan Pardakhtchi ${ }^{2}$, Zahra Sabbaghiyan ${ }^{2}$ \\ ${ }^{I}$ PhD Candidate of Educational Management, Tehran North Branch, Islamic Azad University, Tehran, Iran \\ ${ }^{2}$ Professor, Educational Management Department, Psychology and Educative Sciences Faculty, Shahid Behesti \\ University, Tehran, Iran
}

\begin{abstract}
Background: The aim of this qualitative study was identifying the effective factors and components in transferring learning to the work environment in in-service training of nurses in hospitals affiliated to the Social Security Organization.

Materials and methods: The method was exploratory research and Data analysis was fundamental.

The sample includes 35 members of hospital supervisor, head nurses, master manager of education and academic professors who work and expert in training transfer. Data were collected by open interview until theoretical saturation was reached. Open and semi-structured interviews were used to collect information and simultaneous analyses of the interview were conducted using open, axial and selective coding. The obtained model was validated by all 35 people and the learning transfer model was developed. Finally, using the feedback method of the participants and the analyst triangulation technique, the validity of the analysis was ensured. In order to measure the reliability of the coding, re-test reliability methods and intra-subject agreement were used.

Results: The factors affecting training transfer could be in 4 dimensions, including personal factors, educational factors, organizational factors and meta-organizational or environment factors.

Conclusion: The results showed this fact that in educational performance process in hospital and achieve the efficiency and effectiveness of education in nurses' performance, we must consider factors affecting training transfer. Because the lack of attention to these factors influencing the transfer process has shown that learning is forgotten over time and eventually a small percentage is transferred to the workplace and a lot of costs are imposed on the hospital without any benefit.
\end{abstract}

Keywords: Training transfer, Training in service, Nurses training, Social security organization.

Cited as: Farhad S, Pardakhtchi MH, Sabbaghiyan Z. Identifying the effective factors and components in transferring learning to the work environment in in-service training of nurses in hospitals affiliated to the Social Security Organization. Medical Science Journal of Islamic Azad University, Tehran Medical Branch 2020; 30(1): 82-91.

Correspondence to: Mohammad Hassan Pardakhtchi

Tel: +989121388813

E-mail: m-pardakhtchi@sbu.ac.ir

ORCID ID: 0000-0002-8403-7091

Received: 26 Nov 2018; Accepted: 28 May 2019 
مجله علوم يزشكى دانشگًاه آزاد اسلامى

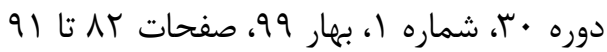

Original

Article

\title{
شناسايى عوامل و مولفههاى موثر در انتقال يادگيرى به محيط كار در آموزشهاى ضمن خدمت يرستاران بيمارستانهاى وابسته به سازمان تامين اجتماعى
}

\author{
ساناز فرهاد'، محمد حسن يرداختجي ‘، زهرا صباغيان'
}

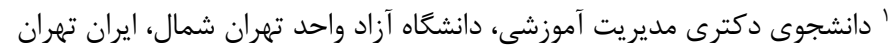

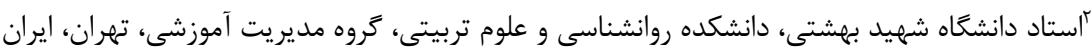

جكيده

سابقه و هدف: هدف /ز /ين مطالعه كيفى، شناسايى عوامل و مولفههاى موثر در /نتقال يادكيرى به محيط كار در آموزشهاى ضمن

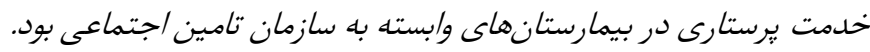

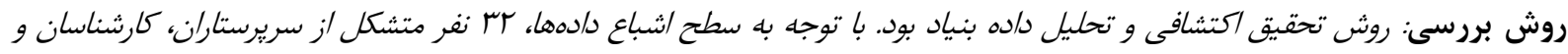

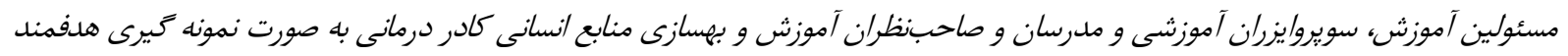

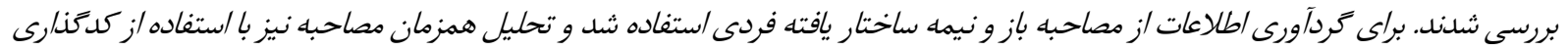

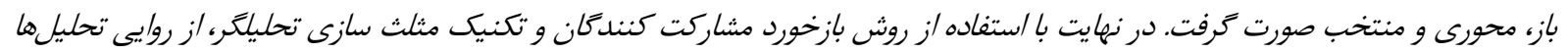

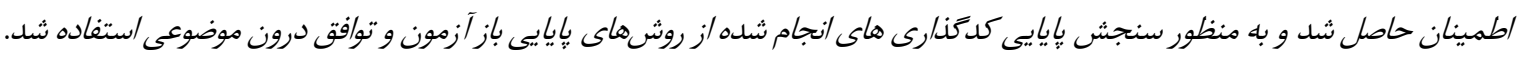

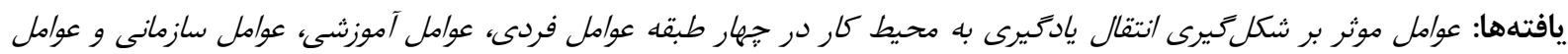

$$
\text { فراسازمانى قرار مى كيرد. }
$$

نتيجه كيرى: نتايج به دست آمله بيان كننده /ين واقعيت هستند كه در فرايند اجراى آموزش در بيمارستانها و و براى رسيدن به به اثربخشى و

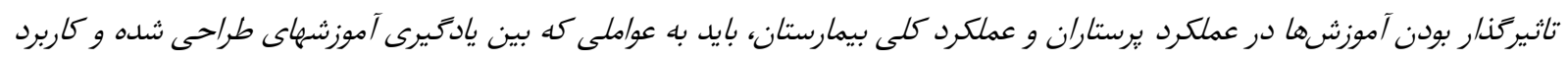

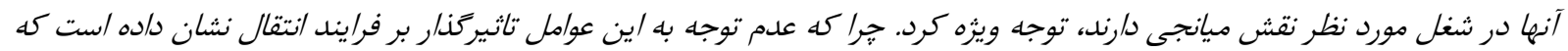

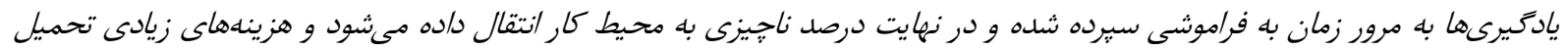

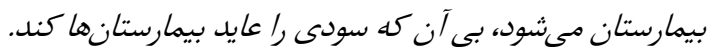

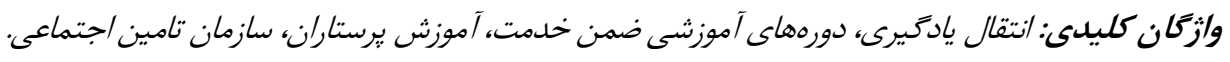

يرستاران با نيازهاى جامعه و بيشرفتهـاى علمى و تغييـرات

مقدمه

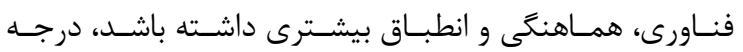

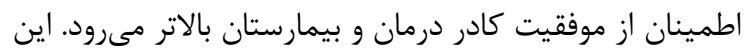

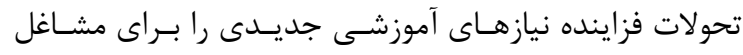

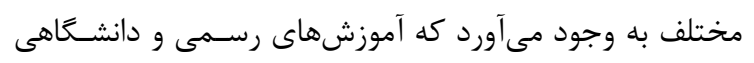

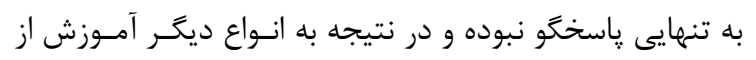

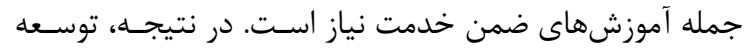

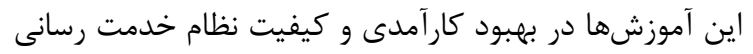

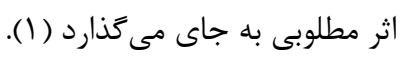
در دنياى در حال تغيير و دَّركونى، ضرورت آموزش و ارتقـاى

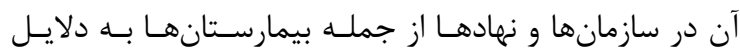

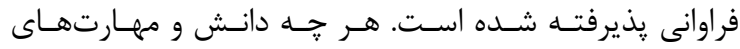




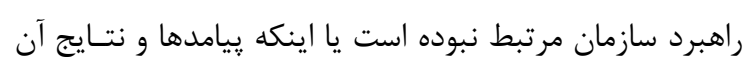

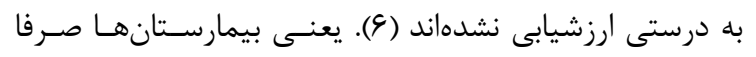

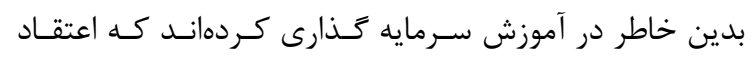

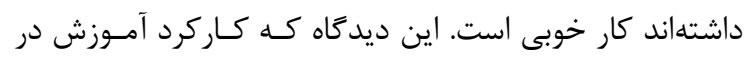

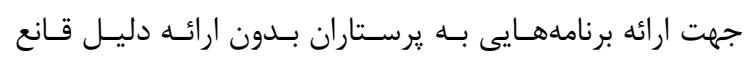

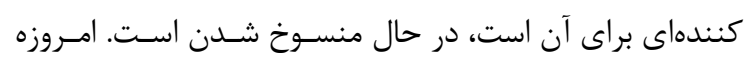

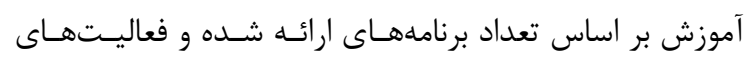

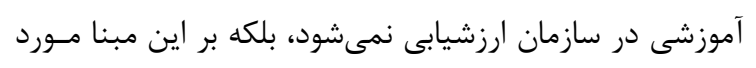

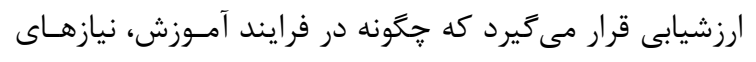

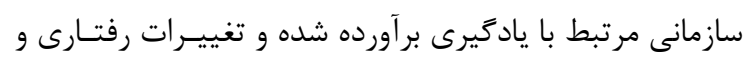

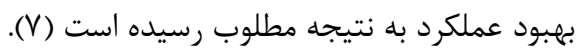

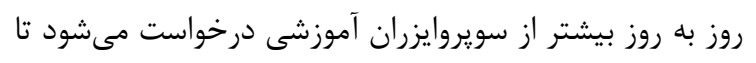

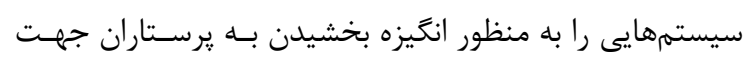

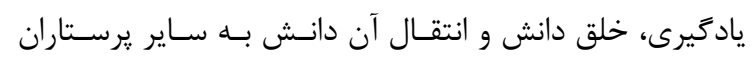

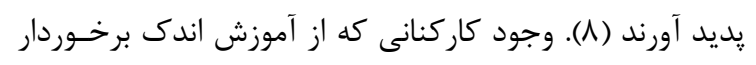

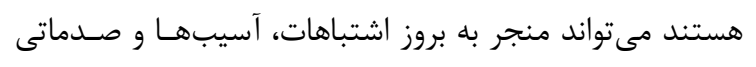

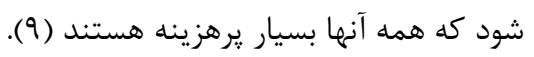

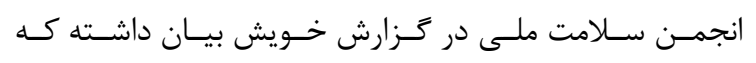

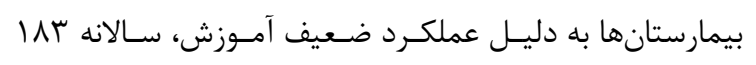

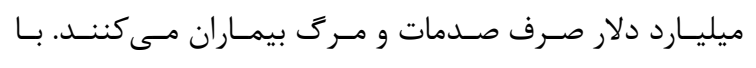

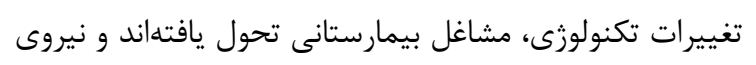

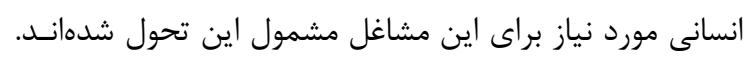

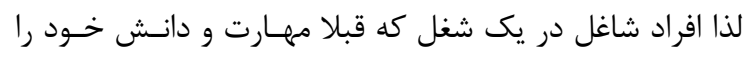

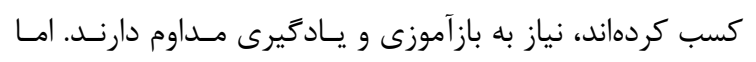

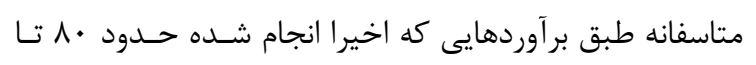

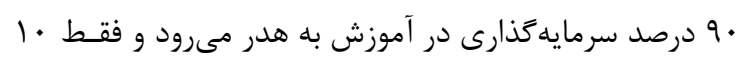

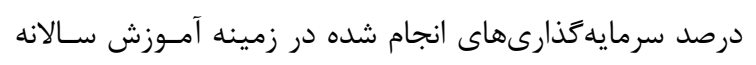

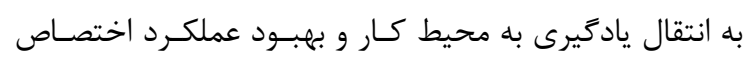

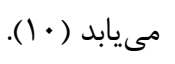

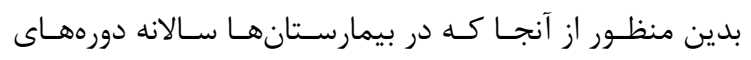

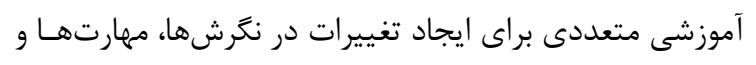

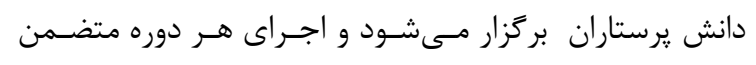

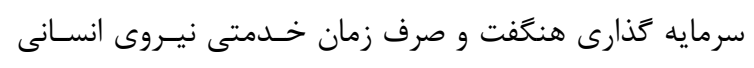

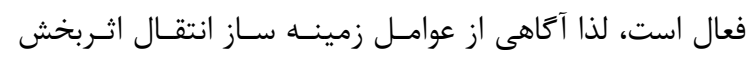

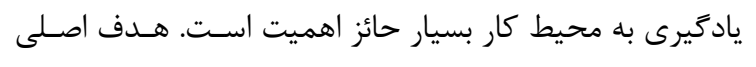

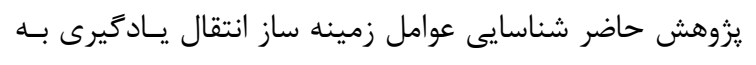

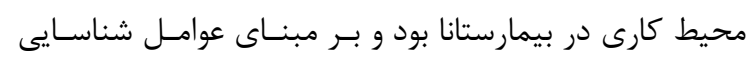

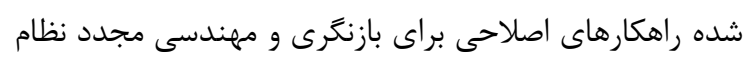
آموزش ارائه شد.

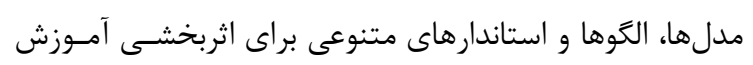

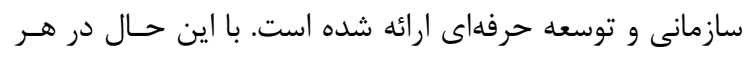

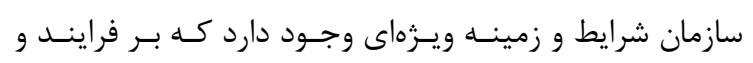

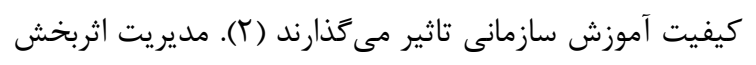

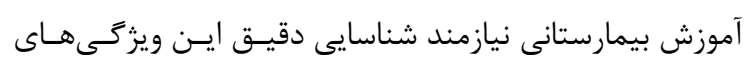

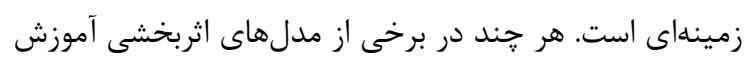

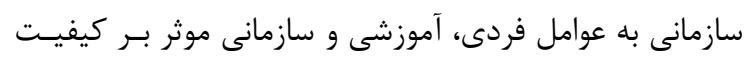

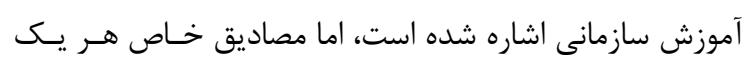

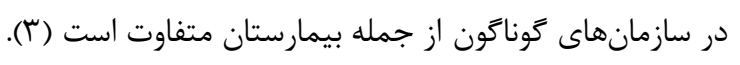

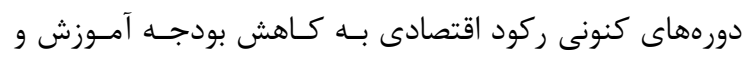

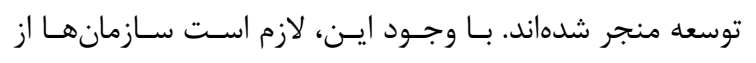

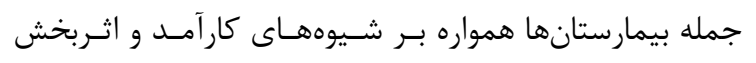

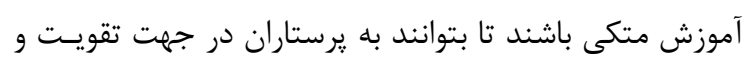
كَسترش مهارتهايشان به منظور بهبود، ارائه ايدههاى نوآورانسه

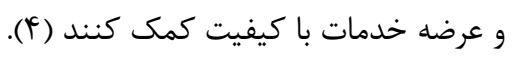

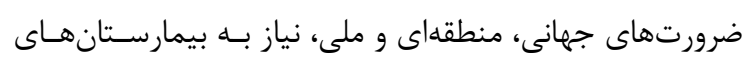

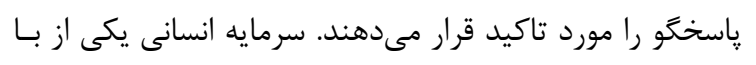

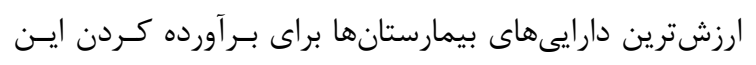

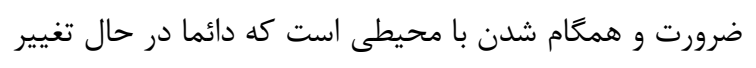

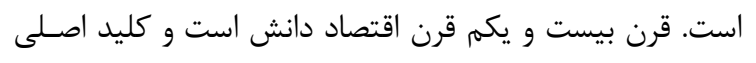

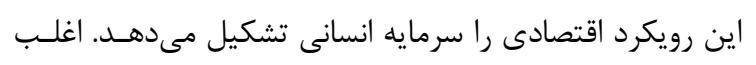

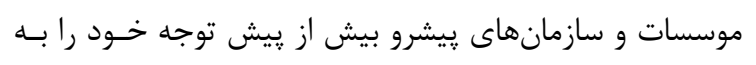

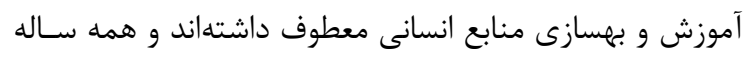
سرمايه كذارىهاى كلانى را به امر آموزش اختصاص مى دهنئسد.

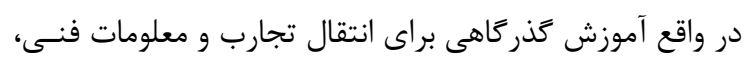

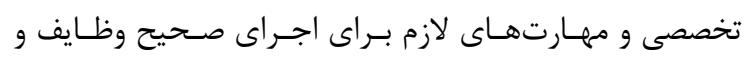
مسوليتهاى شغلى است.

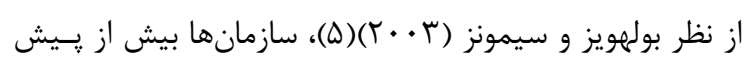

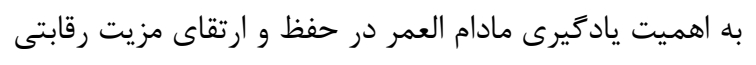

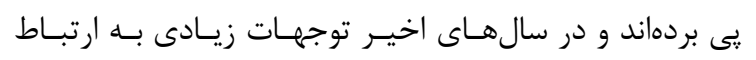

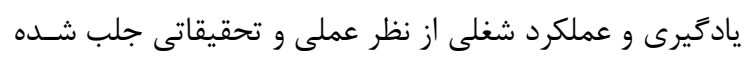

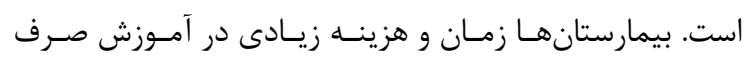

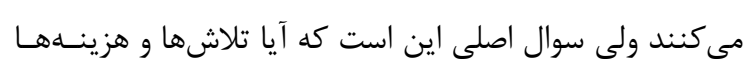

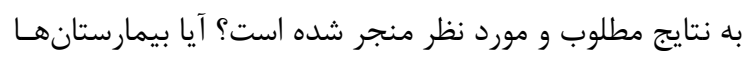

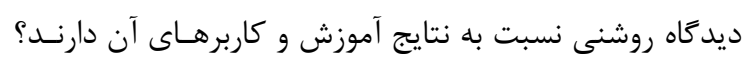

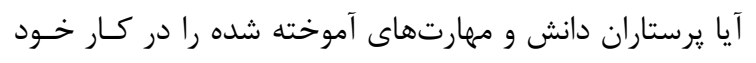

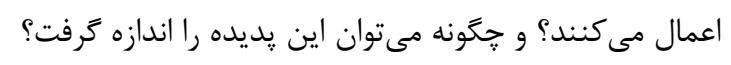

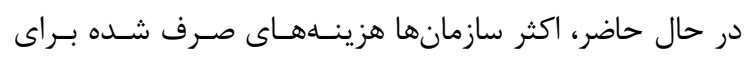

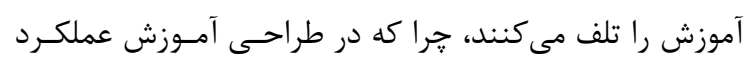
ضعيفى داشتهاند، به اين دليل كه آموزش با مساله عملكـرد يـا 
در اين يزوهش، براى اعتبارسنجى الخَـوى يِيشـنهادى از روش

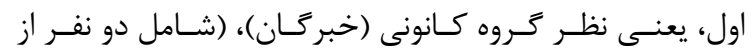

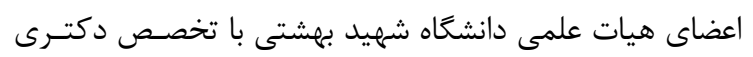

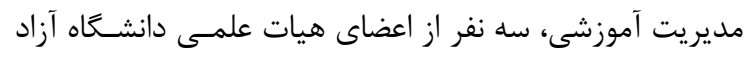

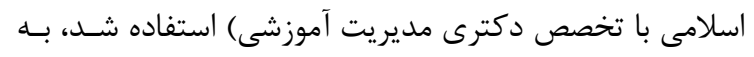

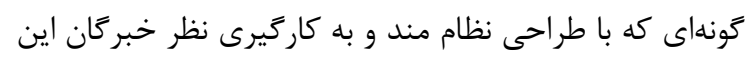

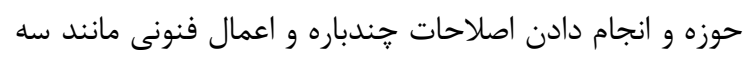

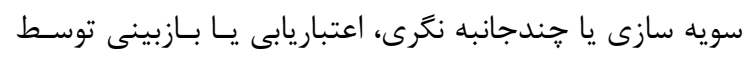

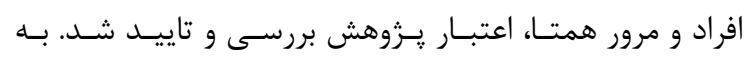

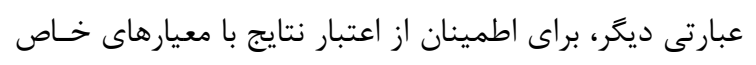

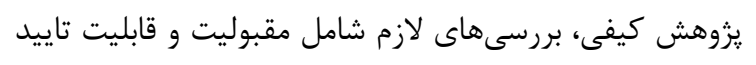

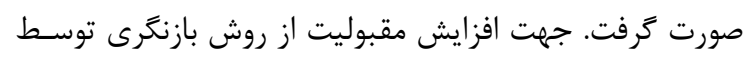

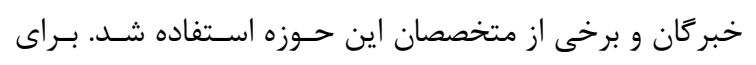

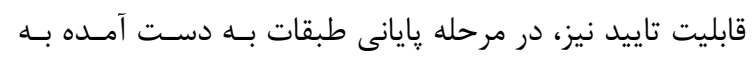

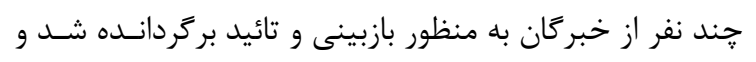
نكات بِيشنهادى اعمال شد.

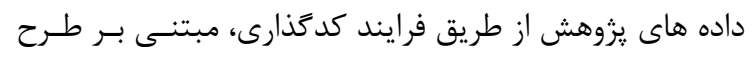

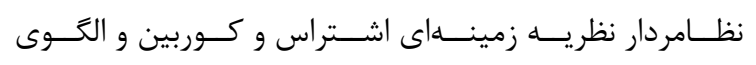

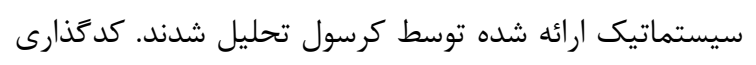

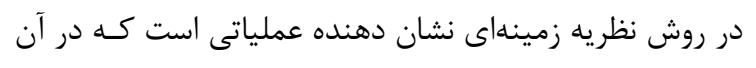

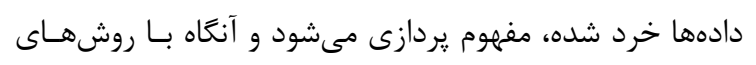

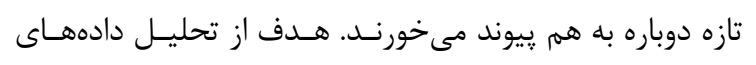

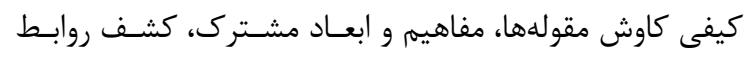
بين اين سازهها و ساخت مدل اجرايى اثربخشى آموزشى مقدى بـود.

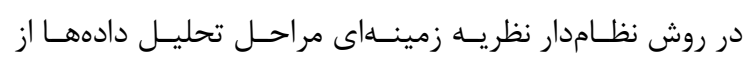

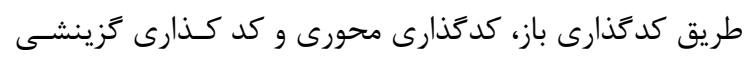

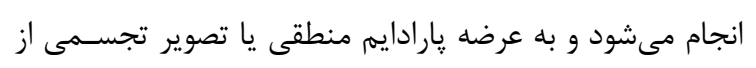
نظريه در حال تكوين پايان مى ميابد.

\section{بافتهها}

يافته هاى كدكذارى باز

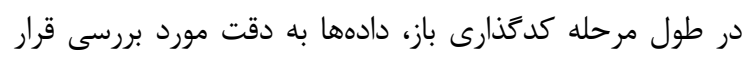

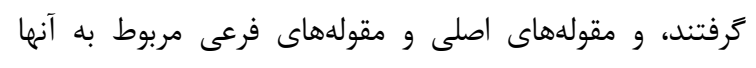

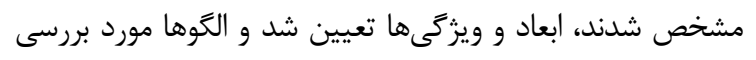
قرار كرفتند. در طى اين تحليلها تكنيكهاى تحليلى ييشنهاد

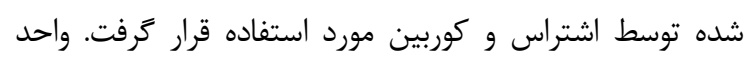

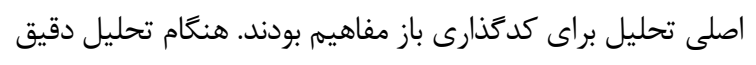

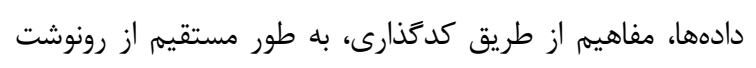

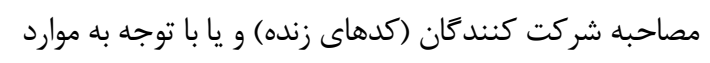

مواد و روشها براى شناسايى عوامل موثر در انتقال يادكيرى به محيط كـار از

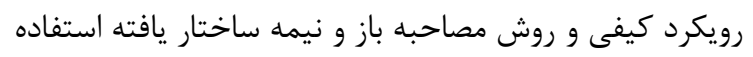

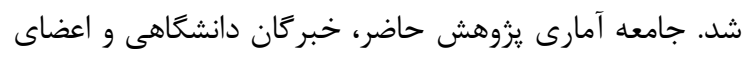

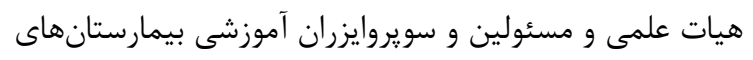

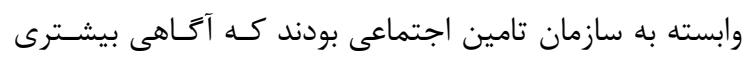

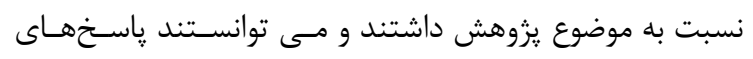

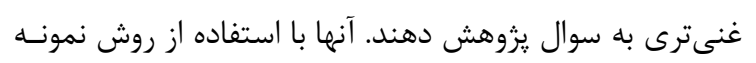

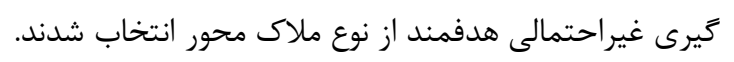

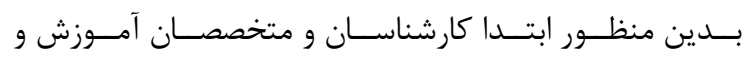

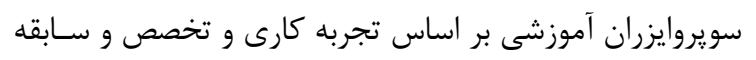

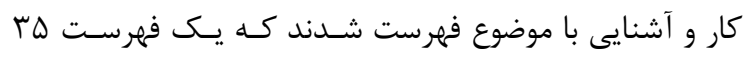

$$
\text { نفره به دست آمد. }
$$

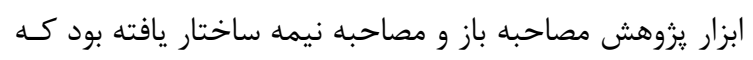

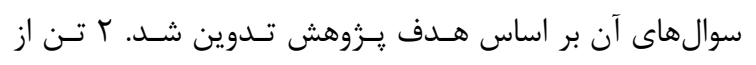

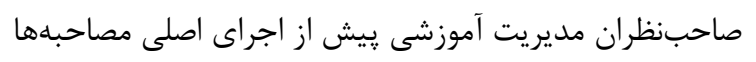

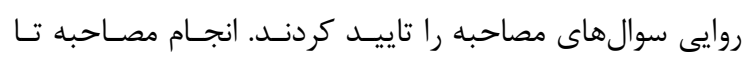
دستيابى به اشباع نظرى ادامه يافت.

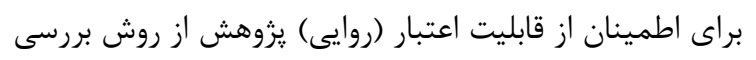

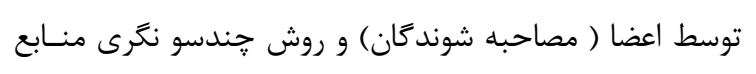

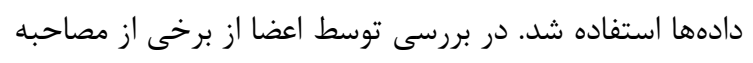

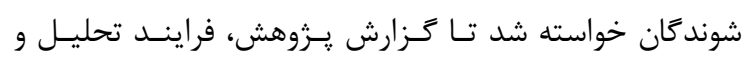

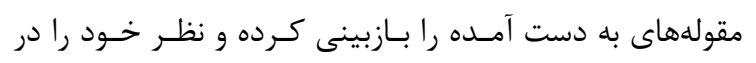

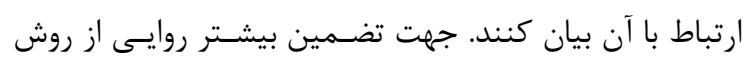

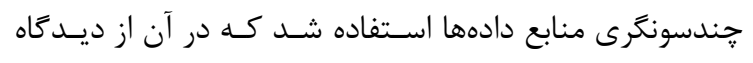

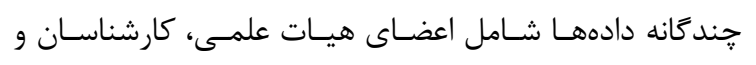

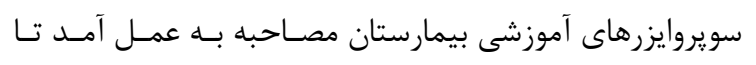

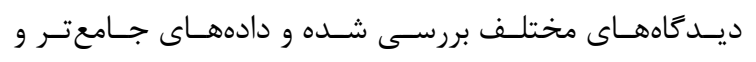

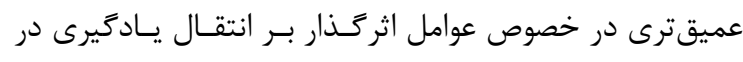

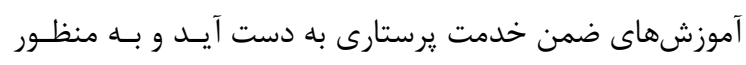

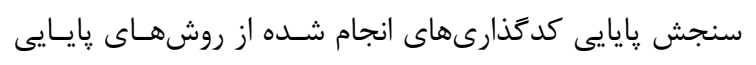
باز آزمون و توافق درون موضوعى استفاده شد.

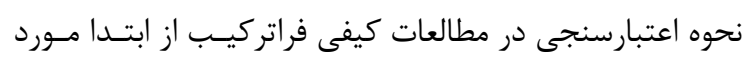

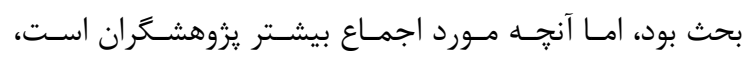

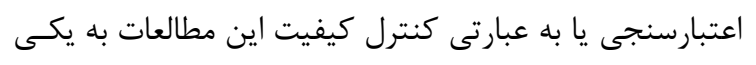

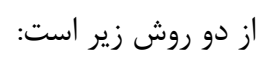

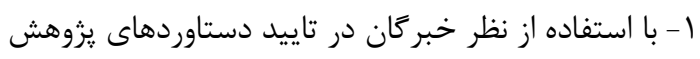

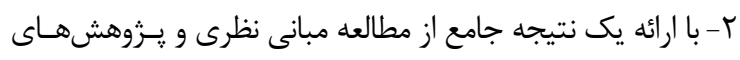

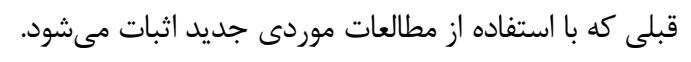


جدول ا. مفاهيم و مقولهاى شناسايى شده در خصوص عوامل موثر در انتقال يادگيرى در آموزشهاى ضمن خدمت ٍرستارى استخراج شده از مصاحبهها

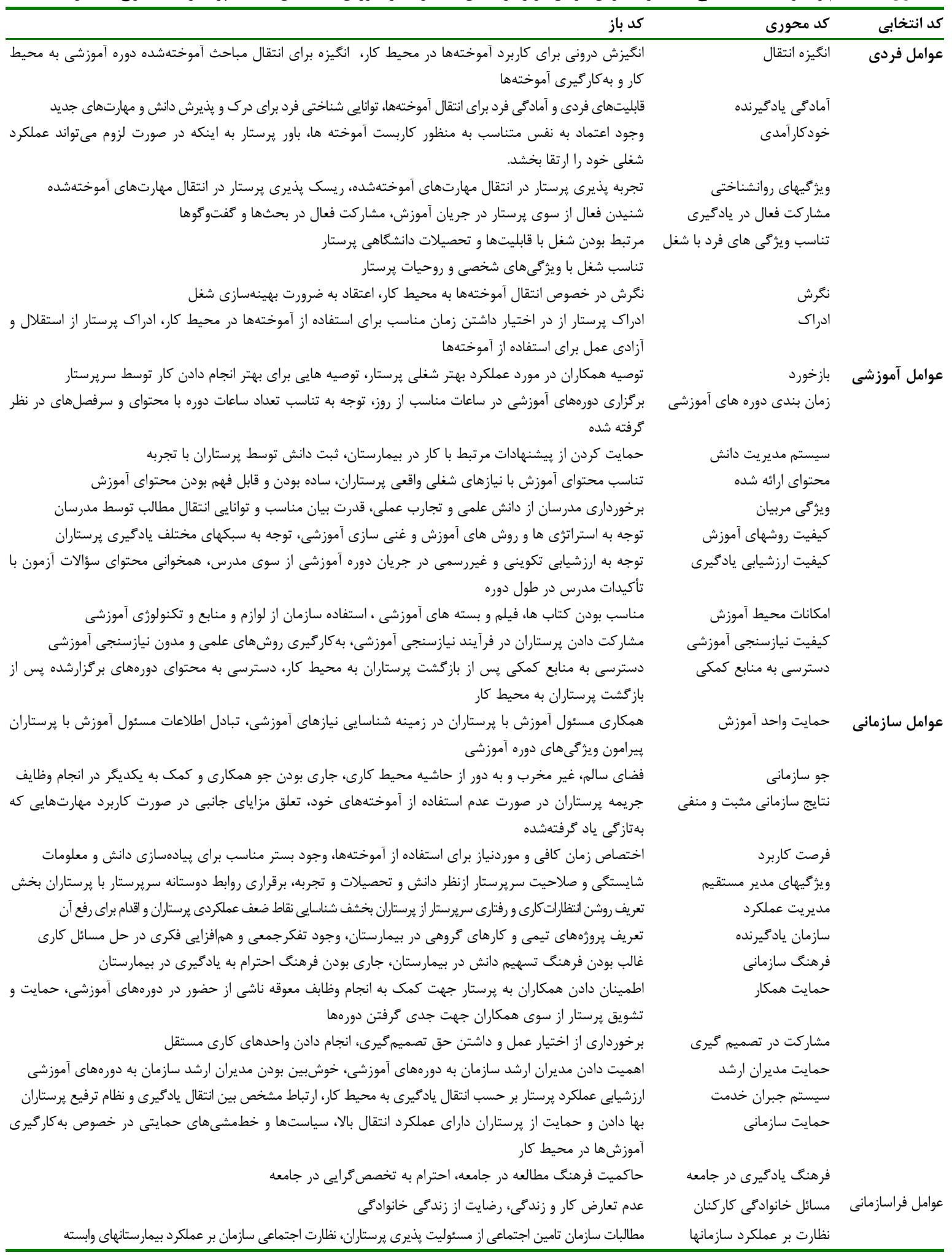

ويزگىها و ابعاد اين مقولات به طور منظه مورد بررسى قرار

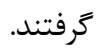

مشترى كاربرد آنها و مبانى نظرى، ايجاد شدند. رونوشت

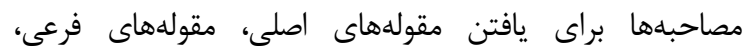


فايلهاى صوتى اطلاعات جديدى ارائه نمىداد. حتى اكر اطلاعات جديدى پيدا مىشد، با طبقه بندى موجود منطبق

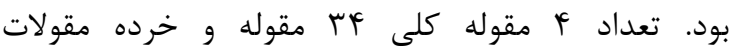
كF بآمورد و ويزگى هاى مربوط به آنها فهرست شد. يافته هاى كد كذارى محورى

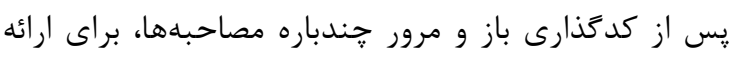
يك طبقه بندى از نتايج تحليل، كام نخست كد كدَّارى محورى انجام شد. يافتهها در قالب سوالهاى مرحله كيفى نائ

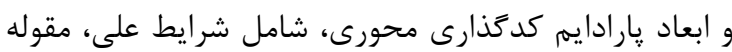
محورى، راهبردهاى اثربخشى آموزش در بيمارستان، زمينه،

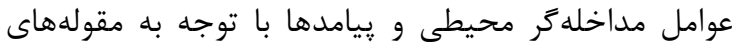

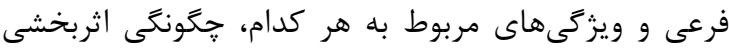

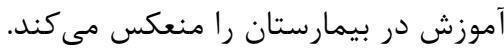
يافته هاى كد كَذارى انتخابى در فرايند كد كذاى انتخابى و تلفيق، متن مصاحبههاى

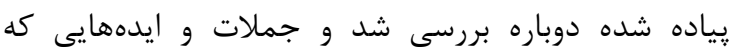
بيانكر ارتباط بين مقولههاى اصلى و فرعى بودند مورد توجه قرار كرفتند. بر اساس روابط به دست آمده، مفاهيم حاصل

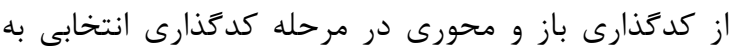

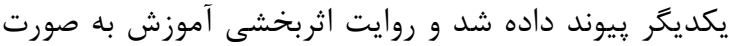
يك مدل مفهومى منعكس شد.

\section{بحث}

نتايج نشان داد كه الكَى تدوين شده مشتمل بر \& عامل

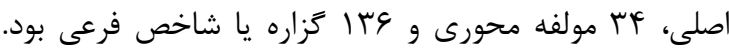
عوامل جهاركانه اصلى عبارت از عوامل فردى، آموزشى،

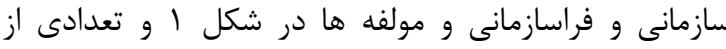

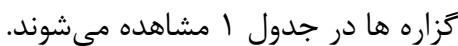

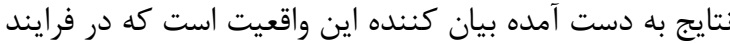

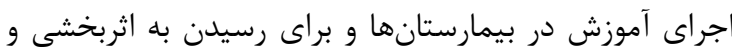
تاثير كذار بودن آموزشها در عملكرد يرستاران و عملكرد كلى بـ براني بيمارستان، بايد به عواملى كه بين يادگيرى آموزشهاى آنداى طراحى شده و كاربرد آنها در شغل مورد نظر نقش ميانجى

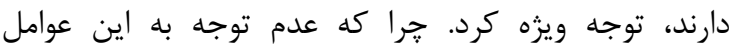
تاثير كذار بر فرايند انتقال، نشان داده است كه يادكيرىها بها به مرور زمان به فراموشى سيرده شده و در نهايت درصد ناجيزى به محيط كار انتقال داده مىشود و هزينههاى زيادى تحميل فرديل بيمارستان مىشود، بى آن كه سودى را عايد بيمارستانها
در انجام كدكَارى باز، نخست دادهاى مربوط به رونوشت مصاحبهها در سطح بند مورد تحليل قرار كرفت. پاسخ به داريه

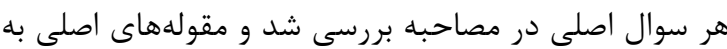
طور موقت نامكذارى شدند. در مرحله بعد دادهها در سطح جمله و عبارت تحليل شدند و خرده مقولات كشف شدند و

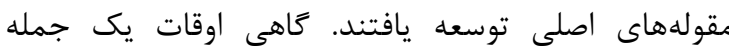
مربوط به بيش از يك مفهوم بود. در نهايت رونوشتها

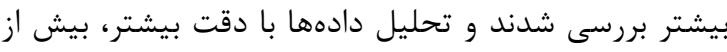
ده بار جهت رسيدن به اشباع منطقى براى مقولههاى اصلى دئى و ويزگى هاى آنها انجام شد. حدود هر مقوله اصلى و

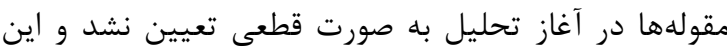
مقولهها در سراسر تحليل مورد تجديد نظر قرار كرفتند. كد تصدي كذارى باز هنگًامى متوقف شد كه:

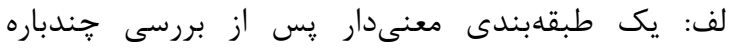
رونوشت مصاحبهها حاصل شد. ب: خرده مقولات و ويزگى ها تكرارى شده بودند. ج: اطلاعات مرتبط و جديدى از رونوشت مصاحبهها يافت

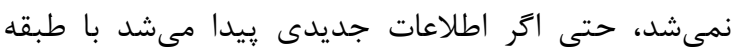
بندى موجود مرتبط بود. موارد و نمونههايى كه در ادامه مى آيند، فرايند كدَذارى

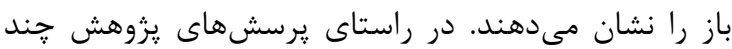

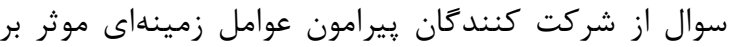

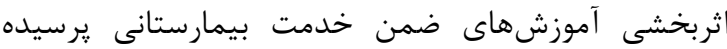
شد. براى مثال جايكاه آموزش در اين بيمارستان جِّونه

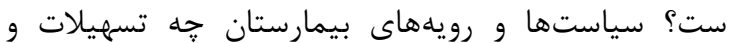
موانعى براى آموزش يرستاران ايجاد كرده است؟ جهات انتظاراتى از آموزشهاى بيمارستانى داريد؟ آيا انتظارات

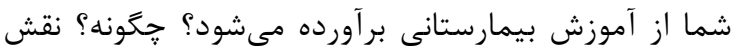

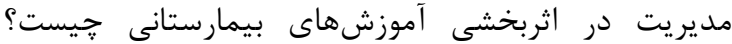

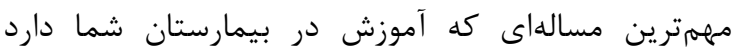

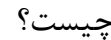
شركت كنند

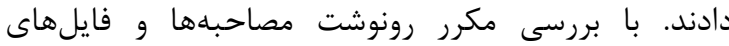
صوتى، مقولههايى، از قبيل تخصيص برني بودجه، حمايت مديريت، رفتارهاى حمايتى، محدوديتهاى اعمالى مديران،

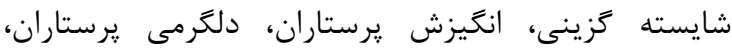

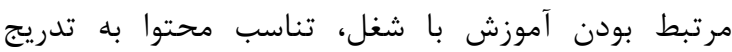
مشخص شدند. يس از جند بار بررسى دقيق رونوشت بـات

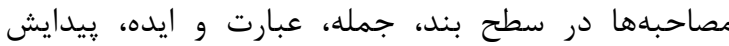
مقولهها تكرارى شد. علاوه بر اين، رونوشت مصاحبهها و 
دسته بندى كردهاند. اگر په اين مطالب بسيار روشنگر هستند اما كاستىهايى بر مباحث موجود مترتب است. بندي

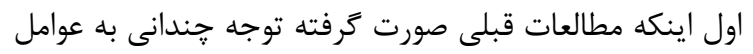
محيطى خارج از بيمارستان (فراسازمانى) نداشتهاند. در اين

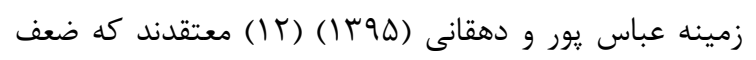
جدى مدلهاى موجود ناديده گرفتن عوامل محيطى است

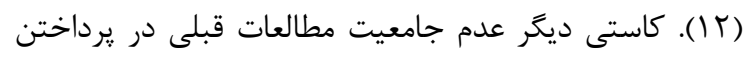
به همه مولفههاى درونى نظامهاى آموزشى يرستاران است. در

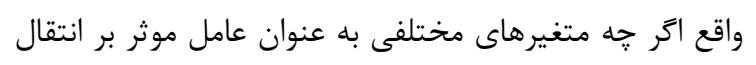

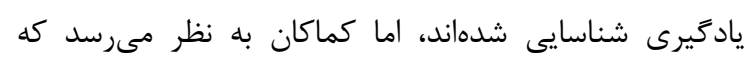

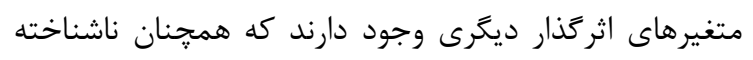

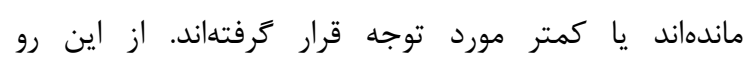

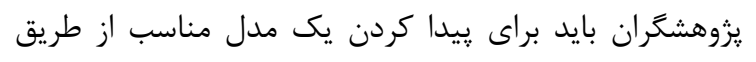

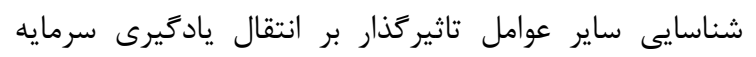

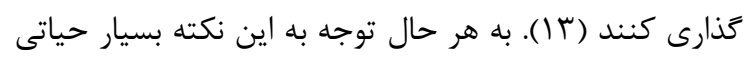

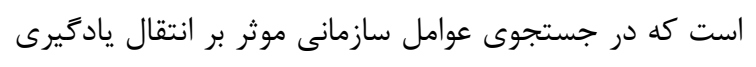
بايد به شرايط فرهنگى و ارزشهاى حاكم به محيط كار به به

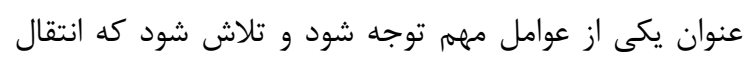

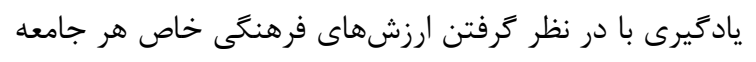

$$
\text { يا سازمان صورت كيرد. }
$$

لازم به ذكر است كه تحقيقات انجام شده بيشتر در مورد مورد

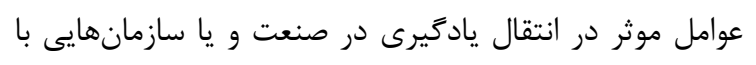

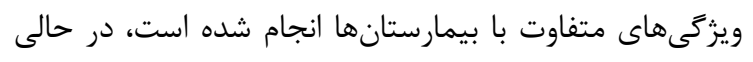

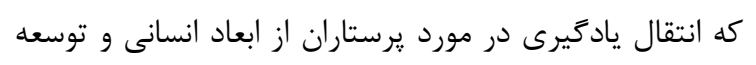

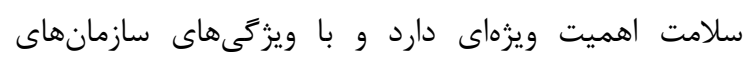
صنعتى و يا خدماتى ديخر بسيار متفاوت است.

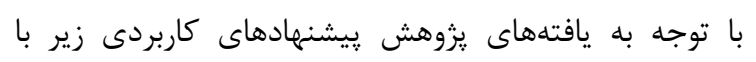

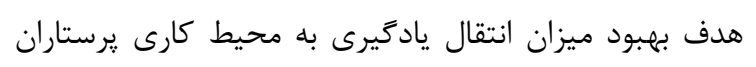

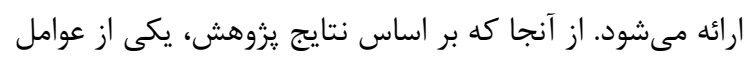

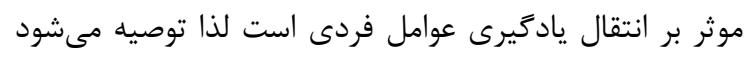

_ـ به صورت رسمى و غير رسمى از تلاشهاى يرستارانى كه به

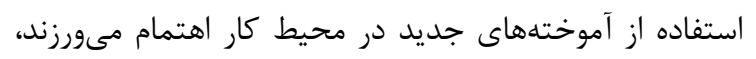

$$
\text { تقدير به عمل آيد. }
$$

ـ يرستاران تشويق شوند كه تجارب مثبت حاصل از حضور در دورههاى آموزشى را با ساير همكاران درميان بخذارند.

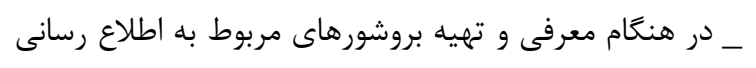

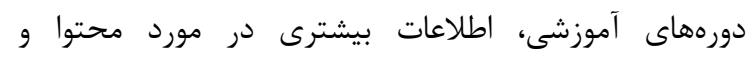

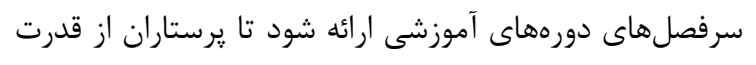

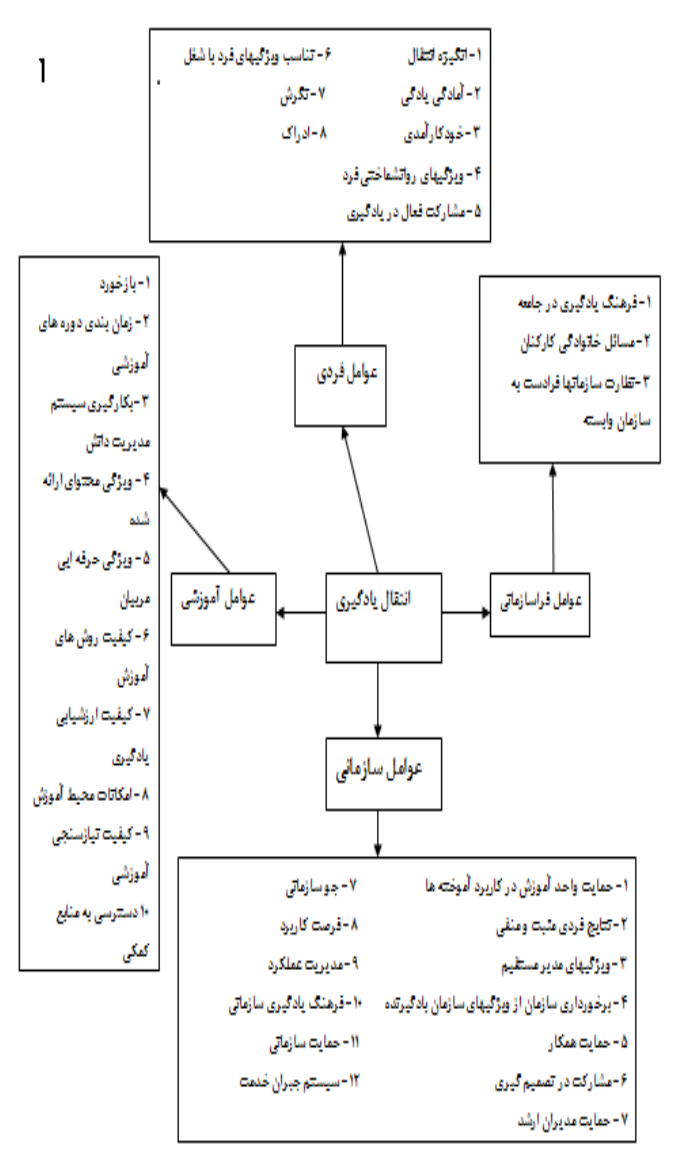

شكل ا. الكوى تدوين شده مستخرج از مصاحبهها توسط نويسند انسان مقاله

همجنين عوامل استخراج شده در اين مقاله يك حالت دوقطبى دارند، به اين صورت كه هر يك از عوامل قابليت مانع

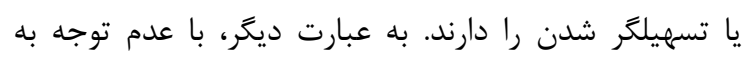

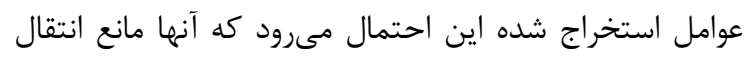
آموزشها به محيط كار شوند و يا با مطالعه و تجزيه و تحليل

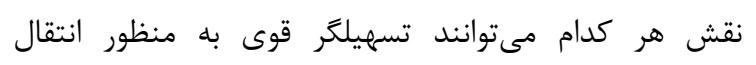
آموختهها به شغل شوند. لذا يِيشنهاد مىشود كه به به اين عوامل

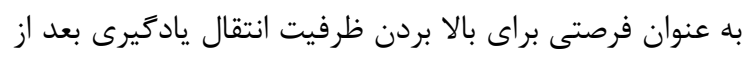

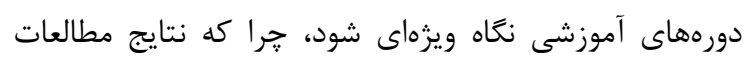

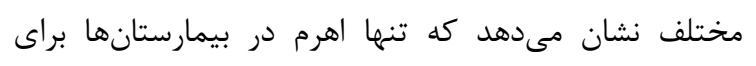

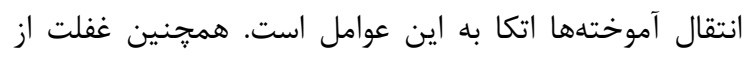

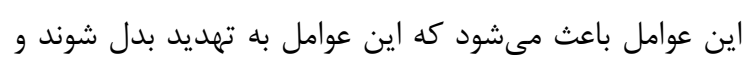

$$
\text { مسير انتقال را دكر گون سازند. }
$$

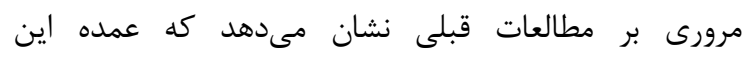

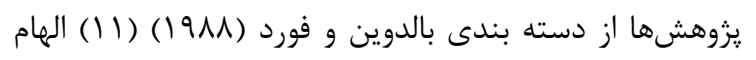

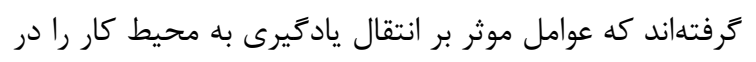
قالب سه دسته عوامل فردى، طرح آموزش و عوامل محيط كار 
ـــــ جاى تعيين نياز از سوى مديران و با رويكرد از بالا به

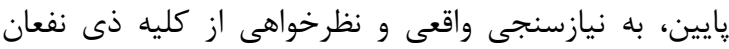
كليدى آموزش از قبيل يرستارسان، سريرستاران، مديران بخشها و صاحبنظران درونى و بيرونى توجه شود.

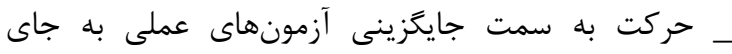
آزمونهاى مداد كاغذى، با هدف تثبيت يادگيرى، كاهش آنشي

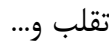
ـ يرهيز از اكتفا به ارزشيابى گرم (بلافاصله پِ از اتمام دوره)

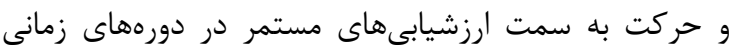

مختلف

ـ در صورتى كه مرحله نيازسنجى آموزشى به طور دقيق با توجه به وظايف شغلى و مشاركت يرستاران انجام شود، به طور

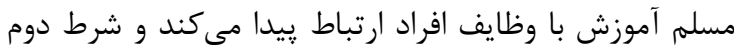

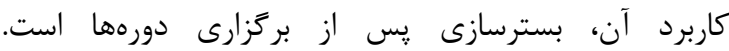
بيمارستانها در يى مطالبه از افراد مبنى بر تغيير عملكرد بر براري طبق دوره آموزشى، بايد در جهت ايجاد امكانات مورد نظر و

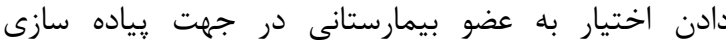

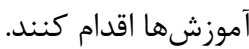
از آنجا كه بر اساس نتايج يزوهش، يكى از عوامل موثر بر انتقال يادگيرى، عوامل سازمانى است، لذا توصيه مى شود كه:

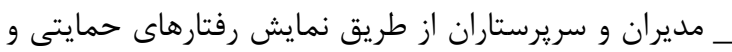
نوع دوستانه، جوى ايمن و حمايت بخش را برائ ارئ انتقال يادكيرى به محيط كار فراهم آورند.

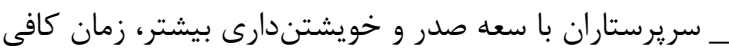
براى كاربست آموختههاى جديد به محيط كار را در اختيار

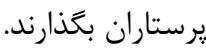
_ افراد متخصصتر، متعهدتر و شايستهتر براى پرت مسئول آموزش بيمارستانى (سويروايزر آموزشى) انتخاب شوند.

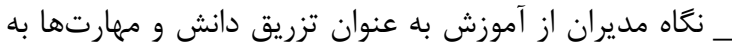

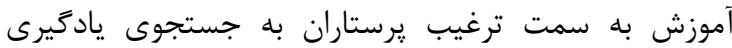

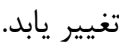
_مديران و سريرستاران در عمل با نشان دادن اهميت

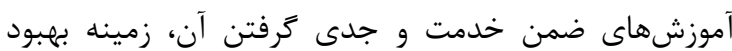
نكرش يرستاران به آموزشهاى سازمانى را فراهم آورند.

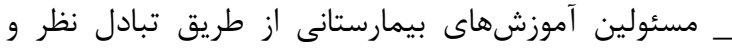
مشاركت دادن يرستاران در مراحل مختلف نيازسنجى

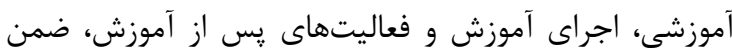

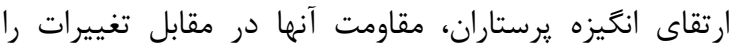

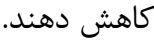

تصميمَيرى بيشترى براى حضور و عدم حضور در دوره

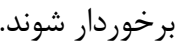

ـ طراحان و مدرسان دورههاى آموزشى، در تعيين حجم

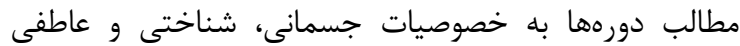
برستاران توجه بيشترى مبذول نمايند.

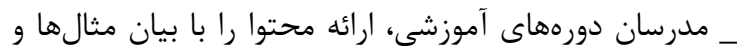
مصاديق كاربردى و عينى همراه گردانند.

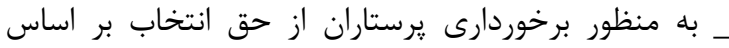
نيازها و علايق خود، تنوع دوره هاى آموزشى بيشتر شود. بران

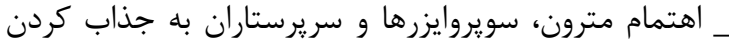

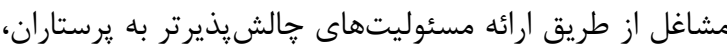

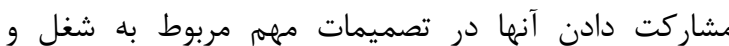
بخشها، دادن آزادى عمل بيشتر به يرستاران.

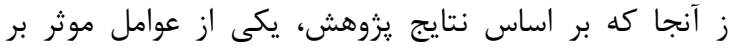

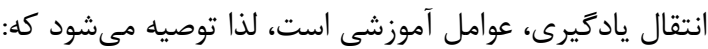
ـ مسئولان بركزارى دورههاى آموزشى، حساسيت و نظارت بيشترى نسبت به تناسب بين سرفصلهاى دوره و آنجه كه واقعا مدرسان دوره تدريس مى كنند داشته باشند. ـ ـ مسئولان آموزشهاى بيمارستانى به تدوين اهداف دقيق، مشخص و قابل اندازه كيرى آموزشى ملزم شوند.

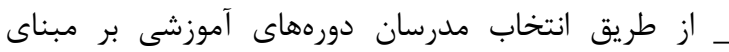
استانداردهاى عملى يذيرفته شده، زمينه يادكيرى بيشتر يرستاران و انتقال اين يادگيرىها به محيط كار را فراهم آورند.

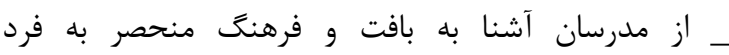
بيمارستانها براى تدريس دوره هاى آموزشى استفاده شود.

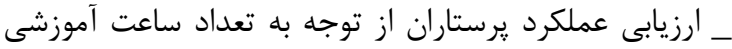
كذرانده شده به سمت كميت و كيفيت يادكيرى انتقال داده شده به محيط كار تغيير كند. ـ انتقال آموختههاى جديد به محيط كار به عنوان يكى از

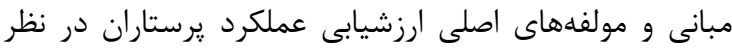

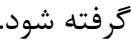
_ مسئولين آموزشهاى بيمارستانى به خصوص سريرستاران و

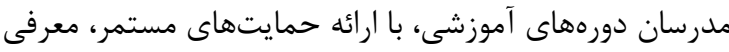
منابع كمكى و غيره زمينه تثبيت و نكخهدارى بيشتر آموختهها

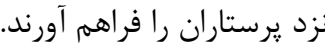
_ در انتخاب و ارائه محتوا دورههاى آموزشى، اكيدا به زمان مان

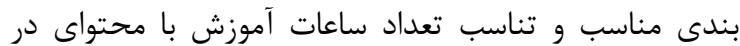
نظر كرفته شده توجه شود.

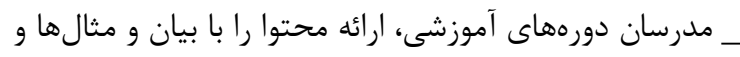
مصاديق كاربردى و عينى همراه كردانند. 
تاكنون در مورد ثاثير عوامل فراسازمانى بر به كاركيرى

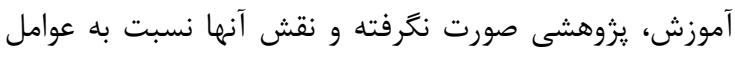

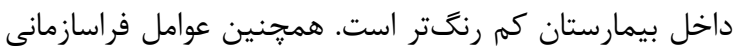

به طور غير مستقيم بر به كاركيرى آموزش تاثير مى كذارند،

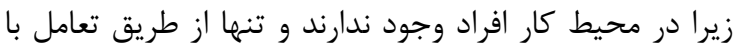

محيط خارج از بيمارستان صورت مى ميكيرد. تاثير اين دسته از

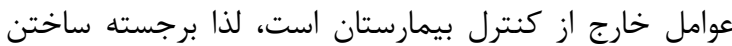

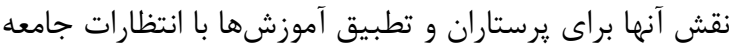

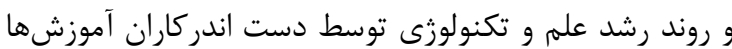

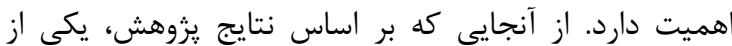

عوامل موثر بر انتقال يادگيرى، عوامل فراسازمانى است، لذا باتيا

$$
\text { توصيه مىشود كه: }
$$

_ دولت در سياست كذارىها و بودجه بندىها به بخش آموزش برستاران در بيمارستانها توجه بيشترى داشته باشد. ـ دولت در ارائه مجوز فعاليت به موسسات خصوصى مجرى ديمارسات دورههاى آموزش غيررسمى، ملاكهاى دقيقتر و ارتهت سخت كيرانهترى را اعمال كند. _ در تعيين زمان بركزارى دورههاى آموزشى، حساسيت بيشترى مبذول شود و شرايط فردى و خانوادىى يرستارئ دران بيش از يِيش مورد توجه قرار كيرد.

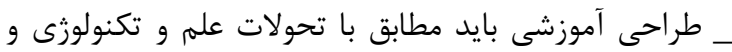

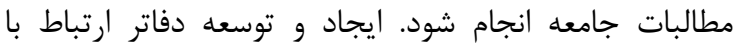
جامعه و همجنين نظام بيشنهادات در جهت ارتباط بيشتر با

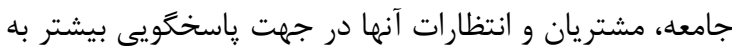
عوامل فراسازمانى و افزايش به كارگيرى آموختهها نيز

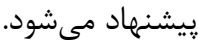

\section{تشكر و قدردانى}

نخًارندكان مقاله بر خود لازم ميدانيند، مراتب تشكر و قدردانى

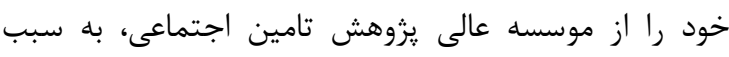
حمايتهايشان از اين مطالعه اعلام دارند.

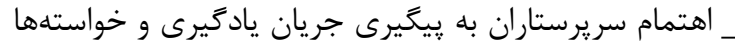

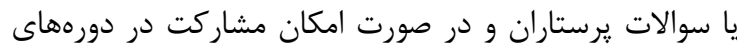
آموزشى به همراه برستاران ئان

ـ ـ احترام به توانيى يرستاران و دادن آزادى عمل بيشتر به آنها با هدف تسهيل امكان انتقال يادكيرى

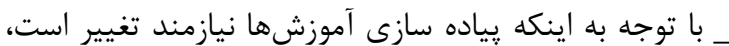
بيمارستانها با به كار گيرى روشها و رويههاى منعطف و قابل

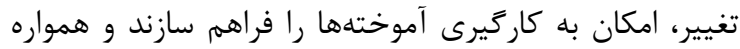
فرهنَ تغيير در مواقع ضرورى و ترغيب رقابت در ميان منابع

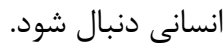
_ حمايتها و مشوقهاى محيطى در مرحله بعد از آموزش كه كه

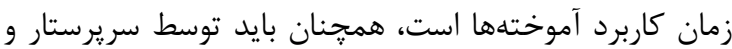
همكاران ادامه يابد. تشويق بايد متناسب با نياز هر فرد باشد و

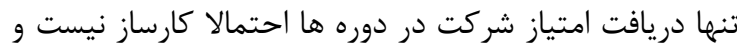
يايدارى تشويق معنوى رانبايد از نظر دور داشت.

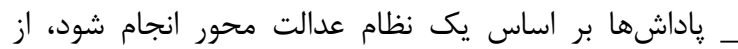

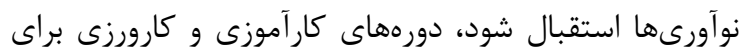
يرستاران در نظر كرفته شود. ـ محيط بيمارستانى به محيطى دانش محور تبديل شود و در در درد

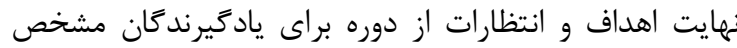

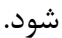
ـ ـيك مكانيزم تشويقى و تنبيهى مناسب براى به كارگيرى مهارتهاى آموخته شده در محيط كار به كار رود.

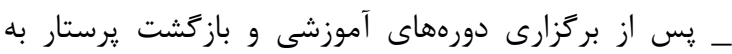

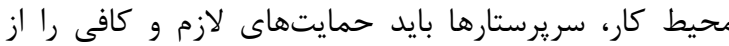

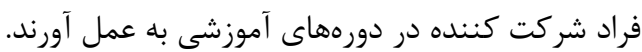
_توصيه مىشود انتقال يادكيرى به عنوان يك عامل بسيار مهرم در فرم ارزيابى عملكرد يرستاران كنجانده شود و عملا

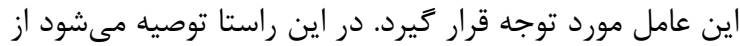

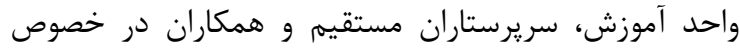
شركت در دورههاى آموزشى و انتقال آموزش به محيط كار

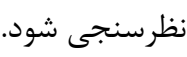

\section{REFERENCES}

1. Mir Kamali M, Matagi Nimor A, Identification factors association with training transfer to work place from vision of specialist of Research and Technology Organization with Delphi method. Journal of Management Improvement 2014;8:73-98. [In Persian].

2. Holton. E. Training transfer evaluation in the public Administration of Catalonia: The MEVIT factors model. Procedia - Social and Behavioral Sciences 2004; 46: 1751- 55.

3. Taheri M. Search and design function model of effective organizational education. Iranian journal of educational Sociology 2016; 3: 137-161. [In Persian]

4. Noe RA, Editor. Employee training and development. New York: McGraw-Hill; 2010. 
5. Simons RJ, Bolhuis S. Constructivist learning theories and complex learning environments. Oxford Studies in Comparative Education 2013;13:13-26.

6. Schneider K, Editor. Transfer of learning in organizations. Switzerland: Springer International Publishing; 2014.

7. Noe RA, Tews MJ. Realigning training and development research to contribute to the psychology of competitive advantage. Industrial and organizational Psychology 2012; 5: 101-104.

8. Walsh JH, Bilsborough W, Maiorana A, Best M, O'Driscoll GJ, Taylor RR, et al. Exercise training improves conduit vessel function in patients with coronary artery disease. J Appl Physiol 2003;95:20-25.

9. Grossman R, Salas E. The transfer of training: what really matters? Int J Training Dev 2011;15:103-120.

10. Weldy TG. The effect of human resource development practices on creating learning organizations: an empirical study on the banking sector in Egypt. J Appl Physiol 2015;3: 130- 137.

11. Baldwin TT, Ford KJ. Transfer of training: a review and directions for future research. Personal Psychology 1998; 41:63-105.

12. Pour Dehghani A. Analytical and comparative study of training transfer system characteristics. General Management 2016; 4:101- 118. [In Persian]

13. Fakhari $\mathrm{CH}$. Design model for evaluation effectiveness of short term in service courses. Medical Education 2015;13: 1058- 72. [In Persian] 